\title{
Fire breve fra H.P. Hanssen til H. V. Clausen
}

ved Troels Fink

Hovedparten af brevvekslingen mellem H.P. Hanssen og H. V.Clausen er velkendt gennem Harald Jørgensens trykte udgave. Fire breve kom dog ikke med i udgivelsen. Disse sidtil ukendte breve fremdrages her af professor Troels Fink, Aabenraa. Brevene giver glimt af det danske arbejde $\mathrm{i}$ tiden frem mod år 1900 - og de antyder de personlige spæendinger $i$ »inderkredsen $\ll$.

Under titlen "To ungdomsvenner« udgav Harald Jørgensen i 1962 en omfattende brevveksling mellem H.P. Hanssen og H. V.Clausen. Der blev derved åbnet en rig kilde til Sønderjyllands historie op imod år 1900.

Man måtte naturligt gå $u d$ fra, at de breve, der fandtes $i$ de to mænds arkiver, repræsenterede hele den indbyrdes korrespondance. Men det har vist sig, at H.V.Clausen i 1889 gav tre breve videre til Johan Ottosen, i hvis arkiv de nu findes (Landsarkivet i Aabenraa). Desuden ligger i H.P. Hanssens arkiv blandt breve fra Gustav Johannsen koncepten til et ikke afsendt brev fra 23. april 1899 til H. V. Clausen. Disse breve gengives her, som supplement til brevudgaven.

Brevene fra 1889 omhandler to større sagsforhold, dels en planlagt rejse for studenter til Sønderjylland og dels forandringerne i Sprogforeningens bestyrelse, efter at sekretæren C. F. Monrad i 1889 var afgået ved døden.

Studenterrejsen var planlagt af bestyrelsen for foreningen $4 \mathrm{~S}$ (Studentersamfundets sønderjyske Samfund). Der måtte ved en sådan samlet rejse udvises den største diskretion for ikke at give de tyske myndigheder muligheder for at forpurre rejsen ved at nægte de unge studenter indrejsetilladelse. Derfor blev H.P. Hanssen meget vred, da han i Politiken læste en artikel af folketingsmand J. K. Lauridsen om planen. Han opfattede det som angiveri og fandt, at J. K. Lauridsen havde tilføjet Venstres anseelse i Sønderjylland ubodelig skade.

Så galt gik det nu ikke. Rejsen blev gennemfort omtrent efter den plan, der er omtalt i brevet af 6. juni 1889. De tyske myndigheder har næppe haft kendskab til artiklen i Politiken. De blev overraskede, da pludselig en gruppe danske studenter gik i land i Sønderborg og senere en anden gruppe i Årøsund. Yderligere kom en del over landegrænsen. I første omgang spredtes de ud over landsdelen og samledes til sidst i Haderslev, hvor der i Harmonien blev holdt 


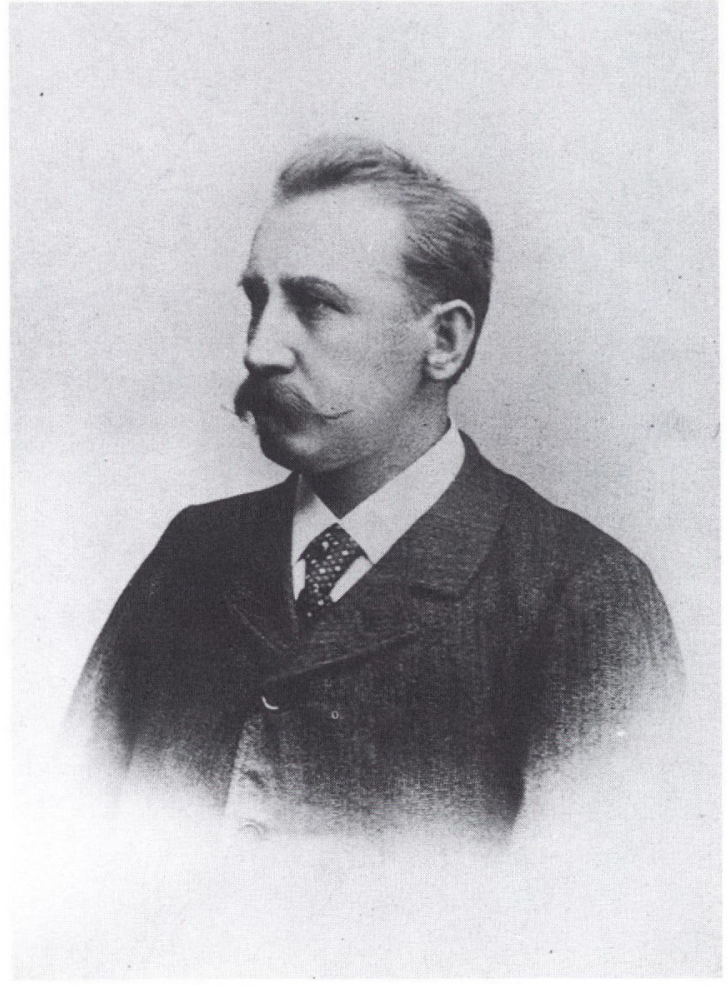

H. P. Hanssen (1862-1936) $i$

30-års alderen. Historishe

Samlinger for Sonderjylland.

et større sold; Harmonien blev overvåget udefra, men det lykkedes ikke for politiet at finde et påskud til at gribe ind.

Den anden sag - valget til bestyrelsen for Sprogforeningen betegner lidt af et vendepunkt i Sønderjyllands historie. I årene fra 1880 til 1889 havde en mere konservativ fløj domineret foreningen. Sekretæren C.F. Monrad forblev livet igennem tro mod sin ungdoms nationalliberale tankegods, og han svingede med dem til højre i dansk indenrigspolitik. Til højrefløjen hørte også dr. P.A Madvig, Haderslev og han regnede med, at hvis redaktør Jens Jessen blev valgt, så ville kursen ikke blive ændret. Men til trods for at bestyrelsen på generalforsamlingen anbefalede Jens Jessen, blev han ikke valgt, han fik kun 10 stemmer. Valget faldt i stedet på lokalredaktøren af bladet Freja i Aabenraa, den tidligere lærer Mathias Andresen, som på det tidspunkt var ganske ukendt $i$ en storre offentlighed. Valget af $M$. Andresen betød, at Sprogforeningen blev »demokratiseret«. Han havde en enestående evne til at give foreningens kulturelle arbejde en breddevirkning, der $\mathrm{i}$ årenes løb viste synlige resulta- 
ter. Men Jens Jessen tilgav aldrig M. Andresen, at han var blevet den foretrukne.

Brevet af 23. april 1899 er uafsluttet og ikke afsendt. Det samme galder det brev af 21.april 1899, der er gengivet i "To ungdomsvenner« s. $270 \mathrm{f}$. H.P. Hanssen var i foråret 1899 udsat for en meget krænkende mistænkeliggørelse. Tilsyneladende har $\mathrm{H}$. V.Clausen ikke straks afvist, hvad der blev sagt om H.P. Hanssen. Det nære venskab blev derved stærkt belastet og var dermed forbi, men i grundsynet på problemerne i Sønderjylland var de fortsat på linie med hinanden.

\section{Breve fra H.P.Hanssen til H.V.Clausen}

Sønderborg, d. 6. juni 1889

Kjære Clausen!

Hvis jeg skulde fremkomme med Indvendinger med Hensyn til Sprogkortets Tekst, ${ }^{1}$ må de nærmest rettes mod de ca. 6.000, der efter Deres Mening taler tysk i den rent danske Del af Landet. Tallet er næmlig for højt efter min Mening, hvis Militæret ikke tages med, og når det er med i Beregningen, må det nævnes. De må næmlig huske på, at end ikke Halvdelen af Embeds- og Bestillingsmand nord for Flensborg Amt er tysktalende. Mindst 4/5 af Lærerne taler sikkert endnu dansk i Familierne, simpelthen af den Grund, at deres Koner ikke med den bedste Vilje kan tale tysk. Det samme gjælder alle underordnede Bestillingsmænd, f.Eks. Brevbærere, Toldkarle o.s.v. Det vil derfor på ingen Måde kunne nå op til 6.000 , med mindre De, som sagt, tager Militæret med. Det bør De nu også gjøre, da det tages med ved Folketællingen, og min hele Bemærkning indskrænker sig derfor til, at der mellem "Embedsstanden « og »de andre« indskydes "Garnisonerne«. Ellers har Sprogkortet mit fulde Bifald. Det er pålideligt, og det er det bedste, der kan siges om et Sprogkort. Det er heldigt, at vi kommer bort fra de gamle Floskler og Fraser, som Mændene fra Halvtredserne endnu stadig opvarter med, uagtet de er helt uholdbare.

Det glæder mig meget, at kortet vil få en så stor Udbredelse. Vi takker meget for de 3.000 Eksemplarer, som vi må få gratis. Da Sprogforeningen og Vælgerforeningen tildels har de samme Mænd til Medlemmer, er jeg bleven enig med Michelsen ${ }^{2} \mathrm{om}$, at Vælgerforeningen påtager sig hele Uddelingen på den Måde, at jeg tilstiller hver af Tillidsmændene et noget større Antal Eksemplarer, end der findes Medlemmer i Kredsen, på den Betingelse, at de tilstiller de af Sprogforeningens Medlemmer, der ikke tillige er Vælgerforeningsmedlemmer, de overkomplette Eksemplarer. 


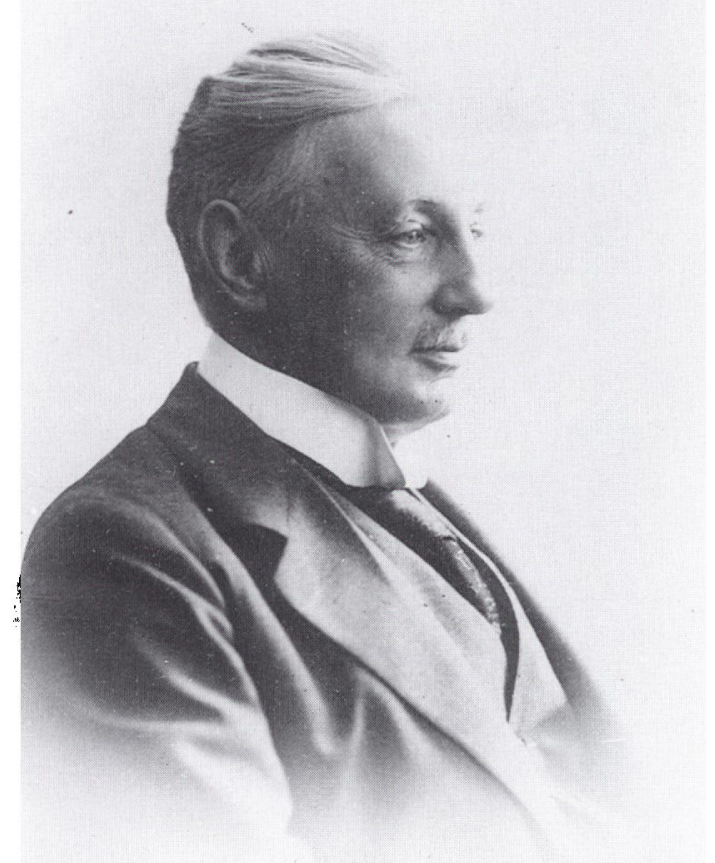

H. V. Clausen (1861-1937).

Historiske Samlinger for Sonderjylland.

Monrad $^{3}$ er jo så død. Madvig ${ }^{4}$ tog de øvrige Bestyrelsesmedlemmer med en Trumf. Han rejste tidlig ned til Flensborg på Begravelsesdagen, fik fat i Michelsen og Petersen, ${ }^{5}$ Aabenraa og forestillede dem, at Jessen ${ }^{6}$ og kun han var egnet til at være Monrads Arvtager som Formand for Bogudvalget. Da de ikke rejste Indvendinger, tog han dem uden videre med til Jessen og bad ham om at overtage Posten. På dette Tidspunkt kom Gustav Johannsen ${ }^{7}$ og P. Skau, ${ }^{8}$ der var holdt uden for Planen, til stede og fik så i Jessens Nærværelse Meddelelse af Madvig om, hvad der var sket. Skrumsager ${ }^{9}$ og Knudsen, Trøjborg $^{10}$ var ikke til stede. Gustav Johannsen er vred og Skau ligeså men Madvig tager sikkert Stikket hjem, i det mindste foreløbig. Det trækker op til Kamp mellem Gustav og Jessen. Jessen søger med stor Iver at samle alle de Tråde, Monrad. har haft, i sine Hænder, og det synes for en stor Del at lykkes. Søndagsbladet får Rossen ${ }^{11}$ nok, men således, at han fremdeles bliver helt afhængig af Jessen, og det er derfor i Virkeligheden ham der får det. Monrads 
Post overfor "Dannebrog « ${ }^{12}$ anstrænger han sig også for at få, men det lykkes nu næppe, da det vil være en fornærmelse overfor Gustav Johannsen.

Jeg forstår ikke, hvad der går af Friis-Fredsted. ${ }^{13}$ Det er snart et Par Måneder siden han blev bemyndiget til at sende en officiel Indbydelse til 60 Studenter til Kjøbenhavn. Vi har her alt i Orden. Vi får de første 30 Studenter over Korsør, 18 går i Land her, 12 ved Brunsnæs, og bliver indkvarterede henholdsvis i Als Sønderherred og i Broager Sogn. 2. Dag tilbringes hos deres Værter, 3die Dags Aften ankommer de til Flensborg til nye Værter, 4de Dags Aften til anden Kreds i Aabenraa Amt og Als Nørreherred. De øvrige 30 får vi fra Aabenraa Amt, de indkvarteres i Ullerup, Sottrup og Nybøl Sogne, samt Gråsten; bliver der første og anden Dag, ankommer dog anden Dags Aften til Flensborg, bliver der tredie Dag og rejser fjerde Dag med Korsørdamperen. Nu håber vi at få flinke Folk.

Jeg har travlt med at skaffe Drenge til Mantzius. ${ }^{14}$ Den første Flok ca. 20 fra Aabenraa får Ferie omtrent den 20. Juli og rejser straks efter. Resten jeg antager 80-100 - rejser først i August. En bestemt Oversigt over hvor mange der kommer har jeg endnu ikke.

Hilsen fra min Kone.

Deres hengivne

H.P. Hanssen

Sønderborg, d. 4. Juli 1889

Kære Clausen!

Jeg har i den senere Tid ventet stærkt på Deres Afhandling til "Sønderjydske Aarbøger «. De må endelig finde Udvej til at sende mig den snart, da det er på høje Tid, at Trykningen af andet Halvbind begynder. - Kommer De med Studenterne herover? Eller kommer der andre af mine Bekjendte med herover. Har De i det hele særlige Ønsker med Hensyn til enkelte af Gjæsterne, så meddel mig dem omgående. Bredsdorff-Flensborg ${ }^{15}$ vil helst have 4 musikalske Venstremænd. Kan De udruste dem? Det må De meddele mig, opgiv mig ellers, hvem De synes, at han skal have. Han skal både have 4 af første Hold og 4 af andet Hold.

Planen om Turen af sønderjydske Drenge (Mantzius) til Danmark må nu helt opgives. Hovedårsagen er Optantspørgsmålet, som fremdeles står uafgjort hen, idet ingen Ansøger modtager Svar på deres Ansøgninger. Det er grumme kjedeligt, at det atter skulde ende dermed i År, men det har været mig umuligt at få flere end 40 - 50 Drenge, som vilde deltage i Turen, uagtet jeg har gjort store Anstrængelser, og af disse 40-50 frameldte sig stadigt flere i den senere Tid, da Betænkelighederne ved Turen voksede. På Generalforsamlingen i Åbenrå i Tirsdags besluttede vi så at opgive det hele. 


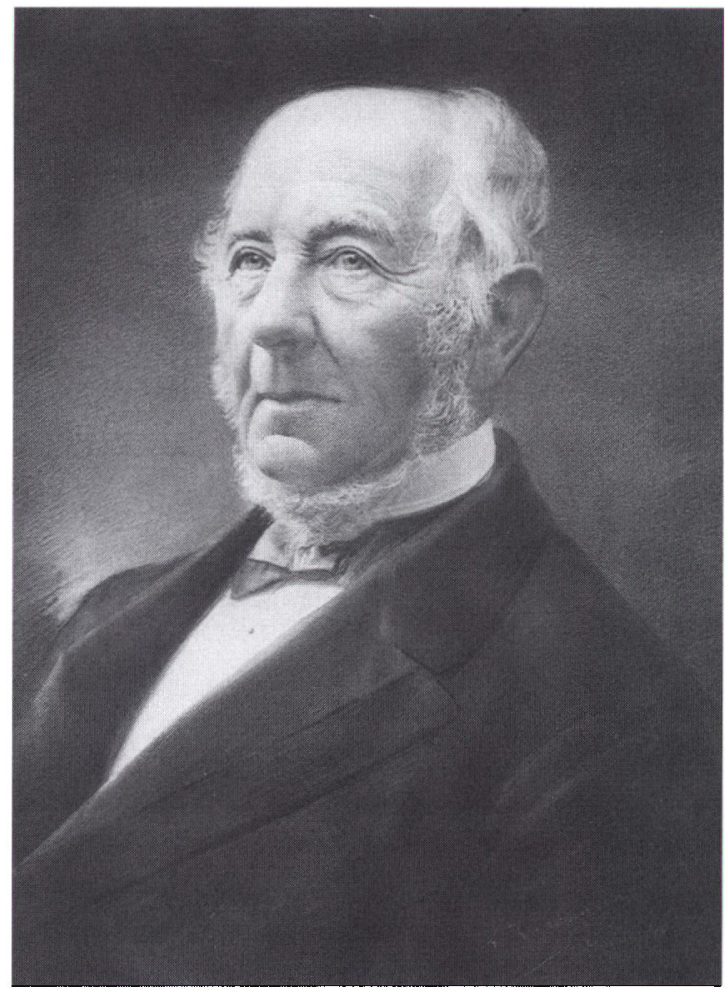

Fysikus P. A. Madvig, Haderslev (1816-99). Historiske Samlinger for Sonderjylland.

Det gik lidt livligt til ved Sprogforeningens Generalforsamling. Da Valg af et nyt Medlem i Stedet for Monrad skulde foregå, rejste Johannsen sig til almindelig Forbavselse og foreslog Redaktør Jessen. Madvig sluttede sig straks til dette Forslag og Michelsen havde på Forhånd givet Hentydninger, som ingen kunde tage fejl af. Trods det faldt der imidlertid kun 10 Stemmer på Jessen. Efter dette Resultat forlangte Madvig Papir, og da han fik det, nedlagde han sit Mandat som Bestyrelsesmedlem med den skriftlige Motivering, at han anså Udfaldet af Valget for et Mistillidsvotum for ham. Der var imidlertid kun få, der beklagede hans Udtrædelse. Bestyrelsen skal nu supplere sig med et nyt Medlem indtil næste Generalforsamling. Bagefter rettede Thomsen, ${ }^{16}$ Roost en Forespørgsel til Michelsen angående den Forchhammerske Bogsamling ${ }^{17}$ som Generalforsamlingen i Fjor bestemte skulde opstilles i Flensborg. Det var imidlertid ikke sket, ligeså lidt som der i det hele er udsendt katalog over den, eller åbnet Sprogforeningens Medlemmer Adgang til den. Bjørnshauge, ${ }^{18}$ Åbenrå, Clausen, ${ }^{19}$ Smedager og jeg sluttede os til Thomsen. Jessen tilbød sig da at give Oplysninger, og Michelsen gav derfor ham Ordet. Da 
han nu var i meget ondt Lune over Valgets Udfald, så blev hans Svar meget uforskammet, idet han gik ud fra, at vi havde insinueret en død Mand, næmlig Monrad. Det gav imidlertid Clausen-Smedager Anledning til under stærkt Bifald at give Jessen en alvorlig Tilrettevisning. Jeg venter nu stærke Angreb og Spydigheder i Flensborg Avis; hvis Retssagerne ikke skulde give Jessen andet at tænke på.

Ved en Statutforandring blev Jessen valgt ind i Vælgerforeningens Bestyrelse. Jeg var personlig stemt derfor af rent praktiske Grunde, fordi Jessen ellers gjennem Flensborg Avis fremdeles vilde have modarbejdet Foreningen. Jeg stemte derfor også på ham. Men iøvrigt møder hans Valg stor Modstand, bl.a. også hos Thomsen-Roost, der udtalte, at det kun ved Overrumpling var lykkedes at få Jessen valgt. Johannsen havde næmlig stillet Forslag om at gjenvælge de 7 afgåede Medlemmer, samt vælge to nye navngivne Medlemmer under ét og ved Akklamation. Og da Thomsen derefter foreslog skriftligt Valg af de nye Medlemmer, erklærede Johannsen på en også efter min Mening uberettiget Måde, at hans Forslag var vedtaget, fordi ingen havde giort Indsigelse derimod, da det blev fremsat.

Der er i den allersidste Tid foregået noget mellem Johannsen og Jessen, som: "Døb Du mit Barn, så smeder jeg Dig et Plovjern«. Ellers intet Nyt. Vi havde et udmærket politisk Møde i Ullerup sidste Søndag. Gustav Johannsen river overalt Folk med sig og gør stor Gavn med sine Møder. Vi håber at bevæge ham til at holde en hel Række Møder inden Valget finder Sted.

Deres hengivne

H. P. Hanssen

P.S. Jeg har nu modtaget Listen over Studenterne. Giv mig omgående en privat Liste med en Fortegnelse over de radikale Venstremænd for at vi kan tage Hensyn dertil.

H.P.H.

*

d. 5. Juli 1889

Kjære Clausen!

Lige nu efter at jeg havde afsendt Kvarterkort og alt var ordnet til Turen, modtog jeg Politiken og læste I. K. Lauridsens Artikel. Intet har i lange Tider harmet mig så meget som dette, der vil skaffe os Politiets Opsyn under hele Turen hernede. Og intet af hvad Misgreb, der er gjort af Venstremænd i de senere År vil skade Venstres Sag, vi Unges Sag hernede, så stærkt som dette Angiveri. Det er blot og bart Angiveri, intet andet, og skal heller ikke være andet. Tyskerne havde ikke et Nys om, at noget vilde ske, alt demonstrativt vilde omhyggeligt blive undgået, der var Udsigt til at alt vilde gå godt så 


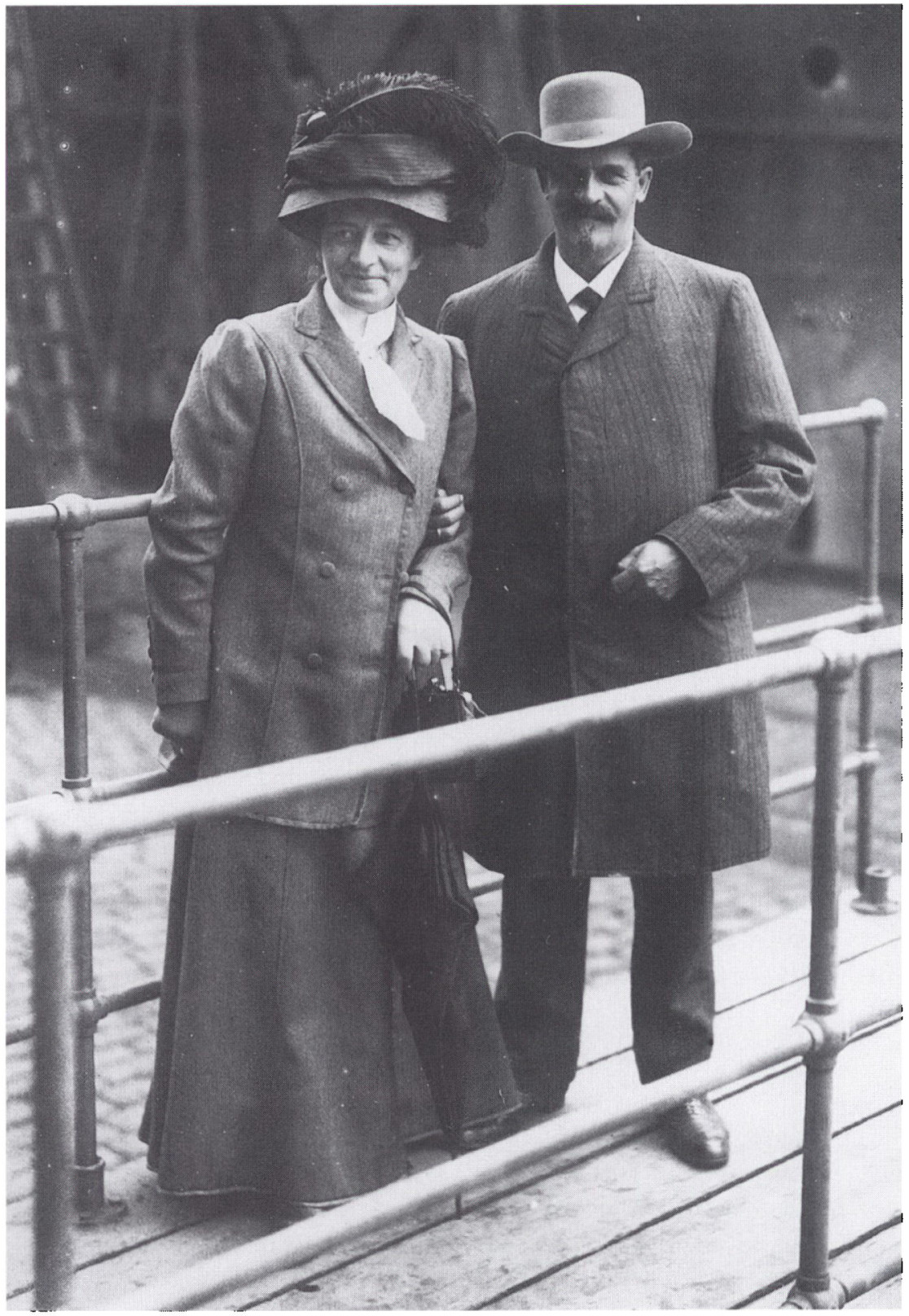

Mathias Andresen (1858-1916) forte som formand for Sprogforeningen fra 1900 og indil sin dod foreningen i mere folkelig retning. Sammen med sin kone Margrethe Junggreen er han her fotograferet pd Amerikabdden Oscar II ved hjemkomsten fra Amerika 1911. Historiske Samlinger for Sonderjylland. 
kommer nu denne Bombe og sprænger alt, ødelægger alt. Og det vil gå som så tidt tidligere Venstre får Skyld for den ene Mands Ubesindighed. Denne ene Mand har skadet vor Sag hernede mere med sin Artikel end to Studentertog kan giøre. Den vil blive udnyttet mod Optantsagen af Hjemmetyskerne og bidrage til at ødelægge den - den vil kort sagt gjort os umådelig Skade. Vilde Lauridsen modarbejde Sagen, så kunde han have gjort det privat, talt imod den i Samfundet og gået til hver enkelt Venstremand og talt med ham, han vilde da endnu have modarbejdet Sagen på en hæderlig Måde. Ved sit lumpne Angiveri er han derimod kommen udenfor, hvad jeg finder hæderligt det mangler blot, at Angivelsen skulde have været anonym!!!

Hvad nu? Vi vil sandsynligvis få Vanskeligheder at kæmpe med. Politiet er bleven skræmt op, og det er ikke umuligt, at der nægtes Studenterne Landgang hernede. Det må jo imidlertid afventes? Og det er vel bedst, at De lader som ingen Ting overfor dem, der har meldt sig som Deltagere. Jeg tillægger Artiklen en sådan Betydning, at jeg straks vil brænde, hvad Breve jeg ikke ønsker Politiet skal se, da jeg anser en Husundersøgelse for mulig.

De må godt sige I.K. Lauridsen på mine Vegne, at de Mænd hernede, der sympatiserer mest med ham i politisk Henseende, betragter hans Optræden som Angiveri, finder at alt, hvad han har udrettet med Artiklen, er at gjøre Tyskerne Spiontjeneste og fremkalde en stærk Reaktion hernede.

I Hast og Harme.

Deres hengivne

H. P. Hanssen

\section{Det følgende, ikke afsluttede brev findes i H.P. Hanssens arkiv blandt breve fra Gustav Johannsen}

\section{Kjære Clausen!}

Berlin d. 23. April 1899

Jeg har haft flere Breve skrevet til Dig, men ikke afsendt dem, da jeg foretrækker mundtlig Forhandling. En Ting maa jeg dog have klaret skriftligt: Du maa gjøre mig den Venskabstjeneste, at faa Gjaldsbeviset over det Laan, jeg har modtaget til mit Trykkeri i Orden en af de første Dage. Det første 1/2 Aars Rente+Afdrag var forfaldent til Udbetaling d. 1. April. Jeg beder Dig om at skaffe mig Dokumentet udfyldt. Aftalen er jo, at Laanet skal forrentes med 5 $\%$, og at der skal betales $1000 \mathrm{kr}$. i aarlig Afdrag i halvaarlige Terminer. Som Sikkerhed for Laanet overdrager jeg Långiverne mine 3 Trykmaskiner. 1) min gamle Hurtigpresse, 2) min ny store Hurtigpresse af Offenbacher Fabrikat og 3) min Liberty-Accidenspresse som Ejendom, indtil Laanet er betalt. Du bedes 


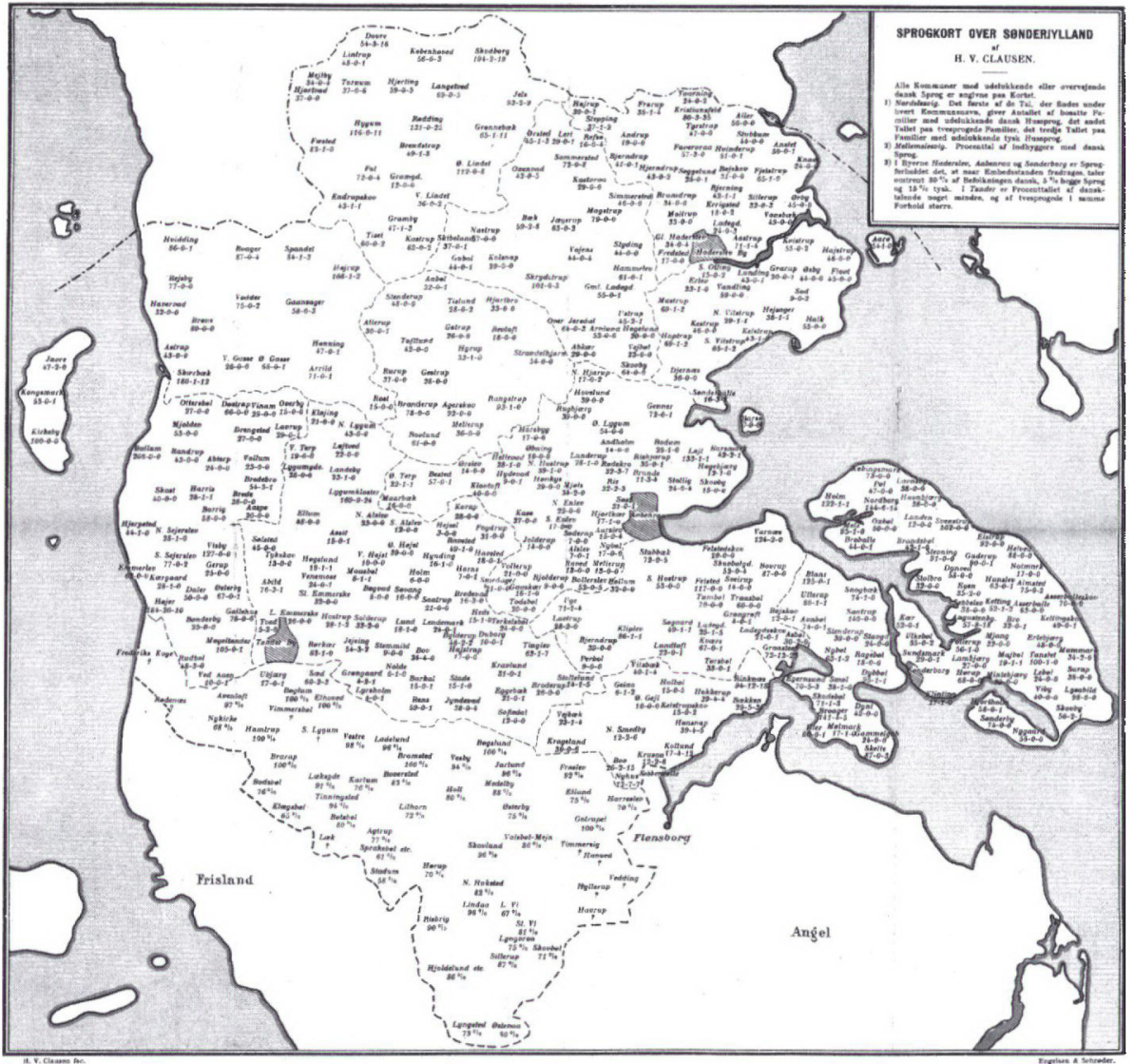

H.V. Clausens sprogkort blev udgivet forste gang 1889 af foreningen $4 S$ som tillog til Politiken $i$ farvetryk. Her er gengivet et kort publiceret kort for 1900. Tallene under kommunenavnene angiver antal familier med udelukkende dansk hussprog, untal tvesprogede familier og antal familier med kun tysk hussprog. 
om at paaskynde Affattelsen af dette Dokument saa meget, at jeg kan underskrive det i denne Uge.

Jeg vil antagelig komme til Kjøbenhavn paa Onsdag. Jeg bliver der kun et Par Dage for at faa mit Penge-Mellemværende med Foreningerne i Kjøbenhavn klaret $\mathbf{i}$ enhver Retning og jeg vil af Hensyn til Stillingen dér være der saa ubemærket som muligt. Jeg vil derfor ikke deltage i Møder. Jeg haaber imidlertid, at Du privat vil meddele mig, hvad der har givet Anledning til at Du og Hjort $^{20}$ er bleven sendt til Flensborg som en Deputation, der skulde undersege mine Forhold bag min Ryg - altsaa som Udtryk for en bestaaende og dybtgaaende Mistillid til min personlige Hæderlighed. Som sagt - jeg vil ikke skrive om den Sag, fordi jeg ikke vil nøjes med Gustav Johannsens og Jessens Fremstillinger eller med Udtalelser i Breve, som jeg har modtaget fra flere Sider. Jeg vil i Modsætning til det Exempel, Du har givet mig og gaa lige til og høre Dine Forklaringer, inden jeg fælder min Dom. Saa meget staar dog fast: Den Mistanke, jeg har været udsat for, er af en saa krænkende og graverende Art, at jeg i Fremtiden maa betragte ethvert Tillidsforhold imellem mig og Organisationerne i Kjøbenhavn som brudt. Efter A. D. Jørgensens Død føler jeg mig fuldstændig uden Støtte i politisk Henseende i Kjøbenhavn, og det er derfor $i$ alle Henseender rigtigt at andre overtager.

(Brevet er ikke afsluttet)

\section{NOTER}

1. H. V.Clausen havde gennem 1880 'erne gennemvandret Sønderjylland og derved skaffet sig et enestående kendskab til de nationale forhold. Han interesserede sig meget for topografi og illustrerede ofte sine resultater med oversigtskort. Sml. hans artikel Folkesproget i Sønderjylland i Sønderjyske Aarbøger 1892 og 1893.

2. Jakob Michelsen, Kolstrup var formand for Sprogforeningen 1887-99.

3. Christian Ferdinand Monrad (1815-1889) var i tiden 1851-64 larer ved det dobbeltsprogede gymnasium i Flensborg. Efter 1864 drev han indtil 1878 en dansk pigeskole. I $1880 \mathrm{blev}$ han sekretær for Sprogforeningen og organiserede bl.a. de mange folkebogsamlinger.

4. Poul Anton Madvig var liege. For 1864 var han fysikus i Haderslev, hvor han blev boende til sin ded i 1899. Han var yderst konservativ.

5. J.G. Petersen, købemand i Aabenraa, kasserer for Sprogforeningen.

6. Redaktor Jens Jessen, Flensborg Avis.

7. Gustav Johannsen (1840-1901) var medlem af den tyske rigsdag og den preussiske landdag.

8. Gårdejer Peter Skau, Bukshave (1825-1917).

9. Gårdejer J. N. H. Skrumsager (1841-1921), Københoved.

10. Godsejer Hans Ågesen Knudsen (1831-1917), Trøjborg.

11. Rasmus Peter Rossen (1858-1928), medarbejder ved Flensborg Avis, fra 1889 udgiver af Nordslesvigsk Søndagsblad. Fra 1901 bankdirektør i Tønder.

12. Foreningen Dannebrog var oprettet i 1865 i København. Støttede danske privatskoler, den danske presse m.m. C. F. Monrad var foreningens tillidsmand i Sønderjylland.

13. Gårdejer Iver Friis (1829-97), Fredsted ved Haderslev.

14. Det drejer sig formodentlig om skolemanden Johan Mantzius (1834-1890). Planen gik ud på at invitere børn fra Sønderjylland til et ferieophold $i$ kongeriget. Planen blev ikke virkeliggjort. 
15. Thomas Bredsdorff (1847-1913), direktør for skibsvarftet i Flensborg.

16. Gårdejer Hinrich Thomsen (1845-1919), Roost, kasserer og sekretær i Sønderjysk Skoleforening.

17. Thomas Otto Forchhammer (1811-98), der levede i Rusland, skæenkede en bogsamling til Sprogforeningen.

18. Dyrlæge Jørgen Hansen Bjørnshauge (1831-91) var ejer af bladet Dannevirke.

19. Gårdejer Rasmus Clausen (18141-1909), Smedager i Bjolderup sogn.

20. Niels Hjort (1862-1917), skoleleder. Medstifter af Foreningen af 5.oktober 1898, der skaffede midler til jordkampen i Sønderjylland. 